Resenha 



\section{UM PASSEIO CARIOCA}

Priscila Rosa Martins*

Afinal, mais importante do que o suicídio, mais importante do que a morte, é a vida, que nem sequer pede licença para prosseguir.

(Luiz Carlos Simon)

Podemos afirmar que esta leitura que segue começa e termina em um ponto comum: o Rio de Janeiro. Iniciamos a caminhada no passado, retornando ao seminário promovido pela Fundação Casa de Rui Barbosa, ocorrido em 1988, dando origem, em 1992, a uma publicação que recebe o título: A crônica: o gênero, sua fixação e suas transformações no Brasil. O volume reúne não só o famoso prefácio de Antonio Candido, "A vida ao rés-do-chão", como também os nomes de outros grandes pesquisadores que se dedicaram ao estudo do gênero e das particularidades das produções de cada cronista. Entretanto, é perceptível que o olhar, naquele momento, não se fixa no presente.

O Rio, paisagem que originou e abrigou grande parte dos escritores brasileiros do século passado, recebia destaque nas colunas de jornais na forma de textos que mais pareciam uma conversa diária com o leitor. É tão

\footnotetext{
* Universidade Estadual de Londrina, Estado do Paraná, Brasil. Mestranda do Programa de Pós-Graduação em Estudos Literários. E-mail: catacrese@gmail.com.
} 
evidente esta alusão que se torna imprescindível fazer relação entre produzir crônicas e falar da cidade do Rio de Janeiro; procedimento, aliás, que já aparece no século XIX, na escrita de cronistas como João do Rio. Este fenômeno não passa despercebido por pesquisadores como Beatriz Resende que organizou um volume, em 1995, com estudos acerca do gênero chamado Cronistas do Rio.

Preocupado com uma análise da produção de seu tempo, Luiz Carlos Simon lançou neste ano, pela EDUEL, o livro Duas ou três páginas despretensiosas: a crônica, Rubem Braga e outros cronistas. A edição é composta de dezesseis artigos que fornecem um panorama da produção da crônica no Brasil, suas mudanças, seus suportes, seus autores. Simon, que transporta para sua escrita a preocupação de seu lado professoral, intelectual e leitor, propicia na leitura de seus textos momentos de prazer e de reflexão, com uma escrita leve que favorece o acesso a leitores acadêmicos ou não.

Há que se ressaltar que seu livro muito se aproxima do próprio objeto. Alguns dos textos haviam sido conferências, artigos e capítulos de outros livros publicados; trazem, dessa maneira, uma discussão antiga sobre a crônica e sua suposta transcendência para o livro. Trazem não só o registro de uma parte de sua vida de pesquisas, mas também uma reavaliação de ser pesquisador, segundo afirma: "Acredito que, no nosso ofício de estudiosos da literatura, de tempos em tempos, vale a pena parar e refletir sobre o que nos leva a trabalhar com determinados assuntos, a analisar certos textos que mantêm afinidades entre si" (SIMON, 2011: 57); ${ }^{1}$ fala esta que aparentemente deixa transparecer um possível tom confessional, reforçado pela escrita em primeira pessoa; aproximando-se, assim, de seus interlocutores.

Seria reduzir a importância deste livro se nos apegássemos a um mero preenchimento de espaço no que se refere às pesquisas acerca da crônica. Simon não se detém em apenas discutir os méritos literários do gênero; procura apresentar formas e maneiras que julga mais adequadas para o estudo da crônica, tanto no que diz respeito à tensão - característica recorrentemente abordada pelos pesquisadores, pois é dela que a crônica carece, segundo estes - quanto ao que considera inapropriado, como a afirmação de que sempre existe um narrador na crônica. Para este último, sugere o termo "eu do cronista”, tendo em vista questões da Teoria Literária, no que implicaria

${ }^{1}$ SIMON, Luiz Carlos. Duas ou três páginas despretensiosas: a crônica, Rubem Braga e outros cronistas. Londrina: Eduel, 2011. 
sustentar a existência de um narrador e, ao mesmo tempo, afastando-se de uma possível interpretação autobiográfica que a crônica propicia.

Em seus estudos, mostra algumas das novas configurações que a crônica vem apresentando. Destaca que o tom lírico que havia nas crônicas de Carlos Drummond de Andrade e Paulo Mendes Campos provinha, também, de um vínculo direto com a poesia, que, de certa forma, era trasladado para estes textos do jornal. Característica que, segundo o autor, vemos com menor frequência nas crônicas atuais, pois este "antigo" lirismo parece ceder seu espaço para o humor - este já se fazia presente na geração passada, porém recebe um destaque pelos autores da contemporaneidade. Luiz Carlos Simon se debruça também sobre o novo suporte que está acolhendo a crônica: o blog. Destes textos mais atuais, ressalta que abordar questões da intimidade tem sido uma de suas feições, observação que o autor compreende como constituinte do homem contemporâneo, relacionando esta produção com os estudos de Richard Sennett e Anthony Giddens. No artigo, "Passeios pela intimidade na crônica contemporânea", o professor analisa as últimas antologias de crônicas, bem como o livro Blônicas, e apresenta alguns autores desta jovem geração de cronistas.

Não obstante, vemos nos artigos do professor que o século passado ainda permite resgates. Em "Quando o jornal é a matéria: as crônicas de Antônio Maria", Simon dedica um estudo a este autor que não obteve grande reconhecimento, mesmo contribuindo para jornais por mais de quinze anos, e que somente após seu falecimento recebeu atenção das editoras. Neste ensaio, à medida que percorre as crônicas, diários e biografia, propõe uma resposta a esse suposto esquecimento.

Como o título anuncia, sua dedicação maior é para a obra de Rubem Braga. Já em sua "Apresentação", o autor especifica que seis ensaios são vinculados à produção deste cronista. Tal escolha não causa espanto. Na própria Apresentação e em recentes entrevistas para programas de rádio e jornais, Luiz Carlos Simon confessa que seu interesse pelo estudo da crônica veio à tona, há cerca de dez anos, ao deparar-se com um livro recém-publicado: Um cartão de Paris. Nessa época, Luiz Carlos estava de volta ao Rio de Janeiro, seu estado de naturalidade, para defender sua tese. É justamente focalizando a obra de Braga que Simon faz o recorte de suas pesquisas.

O livro fecha com um capítulo que proporciona uma abertura, novos caminhos no rumo dos estudos da crônica. O pesquisador fornece uma lista com mais de cem cronistas brasileiros que publicaram livros a partir de 1936, 
ano em que Rubem Braga lança seu primeiro livro, O conde e o passarinho, até 2010. Esta bibliografia inclui informações sobre reedições para facilitar a busca pelo material.

Se, para alguns pesquisadores, a crônica até o presente momento não parecia ser matéria que merecia dedicação acadêmica, e que havia sido por ora abordada casualmente por alguns estudiosos, Luiz Carlos Simon oferece múltiplas opções de pesquisas preocupadas com o papel do intelectual e suas influências; com a recorrência de alguns temas na crônica, como a imagem da mulher e os animais, ou por meio da análise pormenorizada do gênero a partir da inserção e relações deste nos meios midiáticos. 